\title{
KINETIC AND EQUILIBRIUM STUDIES OF METHYLENE BLUE REMOVAL FROM AQUEOUS SOLUTION BY ADSORPTION ON TREATED SAWDUST
}

\author{
Olugbenga Solomon Bello, Oladipo Mary Adelaide, Misbaudeen Abdul Hammed, \\ Olalekan Abdul Muiz Popoola \\ Ladoke Akintola University of Technology, Department of Pure and Applied Chemistry, \\ P.M.B 4000, Ogbomoso, Oyo State, Nigeria \\ osbello@yahoo.com
}

\begin{abstract}
The aim of this study is to use treated sawdust as an adsorbent for the removal of methylene blue (MB) dye. The adsorption equilibrium and kinetics of methylene blue dye on this adsorbent were then examined at $25{ }^{\circ} \mathrm{C}$. The adsorption isotherm of the methylene blue on the treated adsorbent was determined and correlated with common isotherm equations. The sorption data were then correlated with the Langmuir and the Freundlich adsorption isotherm models. The Langmuir isotherm exhibited a better fit for the adsorption data than the Freundlich isotherm with maximum monolayer adsorption capacity of $236.16 \mathrm{mg} \mathrm{g}^{-1}$. The kinetics of methylene blue adsorption on the treated adsorbent has also been studied by fitting the data in the Lagergren's first order, the Ho-McKay's pseudo second order, the Elovich and the Intraparticulate kinetic models. It was observed that the removal of methylene blue over the treated adsorbent undergoes the second order processes at all the concentrations of the dye. The kinetic parameters of this best-fit model were calculated and discussed.
\end{abstract}

Key words: sawdust; adsorbent; dye; kinetic models; adsorption isotherm

\section{СТУДИЈА ЗА КИНЕТИКАТА И РАМНОТЕЖАТА ПРИ ОТСТРАНУВАЫЕ НА МЕТИЛЕНСКО СИНО ОД ВОДНИ РАСТВОРИ СО АТСОРПЦИЈА ВРЗ ОБРАБОТЕНИ СТРУГАНИЦИ}

\begin{abstract}
Проучувана е употребата на обработени струганици како атсорбент за отстранување на бојата од метиленско сино (MC). При $25^{\circ} \mathrm{C}$ се испитувани атсорпционата рамнотежа и кинетиката на преминувањето на бојата на метиленско сино врз споменатиот атсорбент. Атсорпционата изотерма на МС на обработениот атсорбент е определена и корелирана со вообичаени изотермни равенки. Потоа потадоците за сорпцијата се корелирани со Лангмјуровиот и Фројндлиховиот атсорпционен и изотермен модел. Подобра согласност за атсорпционите податоци покажува Лангмјуровата изотерма (отколку Фројндлиховата) со максимален еднослоен атсорпционен капацитет од $236,16 \mathrm{mg} \mathrm{g}^{-1}$. Кинетиката на атсорпцијата на МС врз обработениот атсорбент е изучувана и преку интерполација на податоците од прв ред според Лажергрен, од псевдовтор ред според моделите на Хо-Меккеј, на Елович и внатрепартикуларниот кинетички модел. Покажано е дека отстранувањето на МС од обработениот атсорбент се одвива преку процеси од втор ред при сите концентрации на боја. Пресметани се и дискутирани се кинетичките параметри од методот кој дава најдобра интерполација.
\end{abstract}

Клучни зборови: струганици; атсорбент; боја; кинетички модел; атсорпциона изотерма

\section{INTRODUCTION}

Colored materials and dyes constitute the focus of many environmental concerns because of their non-biodegradable and polluting nature [1, 2]. Thus, prior to their discharge into receiving waters, there is a considerable need to treat col- ored effluents efficiently [3-5]. There are several physicochemical processes for removal and recovery of colored materials and dyes from effluents, out of which adsorption is one of the most effective one [6-8]. The important aspect of the adsorption process is easy regenerability and less operational cost. Adsorption techniques have proven 
successful in removing colored organic species and the choice of the adsorbent is one of the key factors determining the effectiveness of any adsorption process. In recent years, activated carbon has been found as the most widely used adsorbent, as it possesses high capacity for the adsorption of organic materials [9-11]. However, due to the high cost of the activated carbon, the scope of many adsorption studies has been focused on deriving cheaper adsorbents from waste materials. Thus, cheap and effective adsorbents have been developed from various waste materials such as chitin and chitosan [12], peat [13], rice husk [14], clay [15], bottom ash and de-oiled soya [16-18], coal ash [19], crushed bricks [20], sugar beet pulp [21], tea waste [22], feathers [23, 24]. Gupta and his coworkers [25-29] have also made substantial contributions in this area. We have also investigated the use of the activated carbon derived from periwinkle shells in the adsorption of methylene blue dye in recent time [30].

Methylene blue (MB) dye had also been adsorbed using kaolinite and activated carbon produced from palm tree cobs $[31,32]$. The removal of methylene blue from wastewater needs considerable attention. In this present study, treated sawdust has been utilized as an adsorbent for the removal of methylene blue from aqueous solutions. The sorption data have also been correlated with adsorption isotherms and kinetics of adsorption has been studied to determine the efficiency of adsorption process.

\section{MATERIALS AND METHODS}

\subsection{Methylene blue}

Methylene blue (MB) was obtained from $\mathrm{BDH}$. It was used as an adsorbate and was not purified prior to use. Double distilled water was employed for preparing all the solutions and reagents. The chemical structure of the dye is shown in Appendix A.

\subsection{Preparation and characterization of adsorbent}

The sawdust (Gmelina arbhoria) used in this experiment was collected from a local sawmill and dried in sunlight until constant weight was maintained. It was ground to fine powder and sieved to
$150 \mu \mathrm{m}$ size. Sawdust contained water-soluble compounds like tannin, which gave brown color to the effluents during the treatment. The chemical treatment with formaldehyde led to polymerization of the compounds responsible for colorization. Sawdust $(50 \mathrm{~g})$ was washed repeatedly with distilled water and subsequently dried for $24 \mathrm{~h}$ at $233 \mathrm{~K}$ to washout the coloring materials. To improve the physical characteristics further, it was treated with $1 \%$ formaldehyde in the ratio of $1: 4$ (sawdust : formaldehyde, w/v) and $100 \mathrm{ml}$ of $0.2 \mathrm{M}$ $\mathrm{H}_{2} \mathrm{SO}_{4}$. It was heated with cover-over hotplate at $323 \mathrm{~K}$ for $6 \mathrm{~h}$ with occasional stirring. The product was cooled and washed several times with distilled water and finally dried at $333 \mathrm{~K}$ to eliminate all toxicity due to the presence of formaldehyde. The treated sawdust sample $(10 \mathrm{mg})$ was ground with $200 \mathrm{mg}$ of $\mathrm{KBr}$ (spectroscopic grade) in a mortar pressed into $10 \mathrm{~mm}$ diameter disks under 10 tonnes of pressure and high vacuum for $10 \mathrm{~min}$. The FTIR spectra were obtained on a JASCO FTIR3500 spectrometer. The analysis conditions used were 16 scans at a resolution of $4 \mathrm{~cm}^{-1}$ measured between 400 and $4000 \mathrm{~cm}^{-1}$. The FTIR spectra of sawdust, treated sawdust and the sawdust after adsorption are shown in Fig. 1. The FTIR spectra of sawdust showed peaks at 3240, 3015, 1650, $1540,1450,14201250$ and $1160 \mathrm{~cm}^{-1}$ which may be assigned to the $\mathrm{OH}$ group, aliphatic $\mathrm{C}-\mathrm{H}$ group, unsaturated groups like alkene, amide, $\mathrm{CH}$ deformation, $\mathrm{OH}$ deformation, aromaticity and $\mathrm{OH}$ stretch, respectively. The intensity of the peaks were either minimized or shifted slightly in case of treated and adsorbed sawdust, respectively. These results are similar to the ones reported earlier [33].

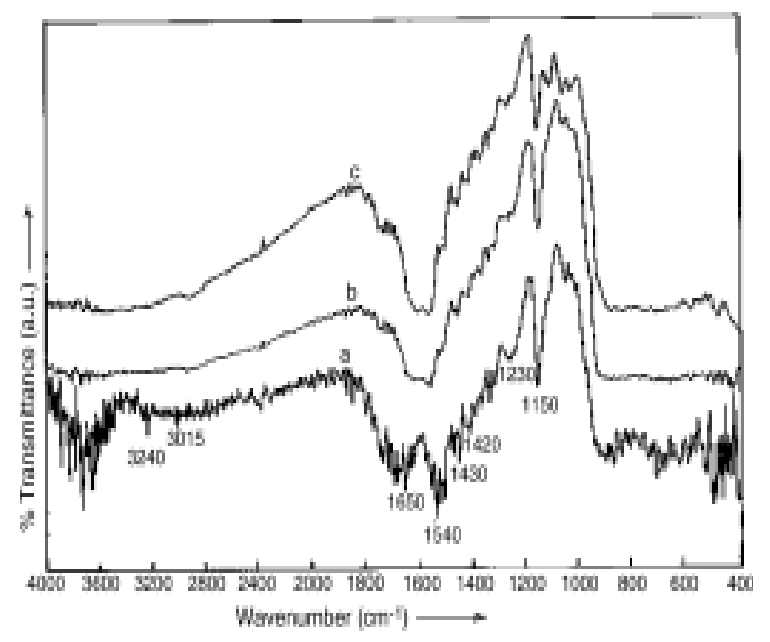

Fig. 1. FTIR spectra of (a) untreated sawdust, (b) treated sawdust and (c) treated sawdust after adsorption 


\subsection{Batch equilibrium studies}

Adsorption isotherms were performed in a set of 43 Erlenmeyer flasks $(250 \mathrm{ml})$ where solutions of dye $(200 \mathrm{ml})$ with different initial concentrations (100-500 $\mathrm{mg} \mathrm{l}^{-1}$ ) were placed in these flasks. Equal mass of $0.2 \mathrm{~g}$ of particle size $(150 \mu \mathrm{m})$ treated sawdust was added to dye solutions and kept in an isothermal shaker $\left(25 \pm 1{ }^{\circ} \mathrm{C}\right)$ for $48 \mathrm{~h}$ to reach equilibrium of the solid-solution mixture. Similar procedure was followed for another set of the Erlenmeyer flask containing the same dye concentration without the adsorbent to be used as a blank. The $\mathrm{pH}$ was adjusted to 7 by adding either few drops of diluted hydrochloric acid or sodium hydroxide $\left(0.1 \mathrm{~mol}^{-1}\right)$. The flasks were then removed from the shaker and the final concentration of dye in the solution was analyzed. The concentration of methylene blue in the supernatant solution after and before adsorption was determined using a double beam UV spectrophotometer (Shimadzu, Japan) at $668 \mathrm{~nm}$. It was found that the supernatant from the treated sawdust did not exhibit any absorbance at this wavelength and also that the calibration curve was very reproducible and linear over the concentration range used in this work.

The samples were filtered prior to analysis in order to minimize interference of the carbon fines with the analysis. Each experiment was duplicated under identical conditions. The amount of adsorption at equilibrium, $q_{\mathrm{e}}\left(\mathrm{mg} \mathrm{g}^{-1}\right)$, was calculated by

$$
q_{e}=\frac{\left(C_{o}-C_{e}\right) V}{W}
$$

where $C_{\mathrm{o}}$ and $C_{\mathrm{e}}\left(\mathrm{mg} \mathrm{l}^{-1}\right)$ are the liquid-phase concentrations of dye at initial and equilibrium, respectively. $V$ is the volume of the solution (1), and $W$ is the mass of dry adsorbent used (g).

\subsection{Batch kinetic studies}

The procedures of kinetic experiments were basically identical to those of equilibrium tests. The aqueous samples were taken at preset time intervals, and the concentrations of dye were similarly measured. The amount of adsorption at time $t, q_{t}\left(\mathrm{mg} \mathrm{g}^{-1}\right)$,was calculated by:

$$
q_{t}=\frac{\left(C_{o}-C_{t}\right) V}{W}
$$

where $C_{o}$ and $C_{t}\left(\mathrm{mg} \mathrm{l}^{-1}\right)$ are the liquid-phase concentrations of dye at initial and any time $t$, respectively. $V$ is the volume of the solution (1), and $W$ is the mass of dry adsorbent used (g).

\subsection{Desorption and regeneration studies}

Desorption studies help to elucidate the nature of adsorption and recycling of the spent adsorbent and the dyes. If the adsorbed dyes can be adsorbed using neutral $\mathrm{pH}$ water, then the attachment of the dyes on the adsorbent is weak. If sulphuric acid or alkaline water desorps the dyes, then the adsorption is by ion exchange. If organic acids like acetic acid desorp the dyes, then the dye is attached to the adsorbent through chemisorption [34, 35].

\section{RESULTS AND DISCUSSION}

\subsection{Effect of agitation time and concentration of dye on adsorption}

A series of contact time experiments for the $\mathrm{MB}$ dye has been carried out at different initial concentrations (100-500 $\left.\mathrm{mg} \mathrm{l}^{-1}\right)$ and at temperature of $25^{\circ} \mathrm{C}$. Fig. 2 shows the contact time necessary for $\mathrm{MB}$ dye with initial concentrations of 100-200 $\mathrm{mg}^{-1}$ to reach equilibrium in $6 \mathrm{~h}$. For the initial concentration of $300 \mathrm{mg} \mathrm{l}^{-1}$ it took $8 \mathrm{~h}$ to reach equilibrium. However, for the $\mathrm{MB}$ dye with higher initial concentrations (400-500 $\mathrm{mg} \mathrm{l}^{-1}$ ), longer equilibrium time of $24 \mathrm{~h}$ is needed. As it can be seen from Fig. 2, the amount of the adsorbed dye onto the treated sawdust increases with time and, at some point of time, it reaches a constant value beyond which no more is removed from solution. At this point, the amount of the dye desorbing from the adsorbent is in a state of dynamic equilibrium with the amount of the dye being adsorbed onto the treated sawdust. The time required to attain this state of equilibrium is termed the equilibrium time, and the amount of dye adsorbed at the equilibrium time reflects the maximum adsorption capacity of the adsorbent under those operating conditions.

The adsorption capacity at equilibrium increases from 67.5 to $410.2 \mathrm{mg} \mathrm{g}^{-1}$ with an increase in the initial dye concentration from 100 to $500 \mathrm{mg} \mathrm{l}^{-1}$ (see Table 1). It is evident that the treated sawdust is efficient in adsorbing the MB dye from aqueous solution, the process attaining equilibrium gradually. 
Table 1

Comparison of the pseudo first- and second-order adsorption rate constants and calculated experimental $q_{e}$ values for different initial dye concentrations

\begin{tabular}{|c|c|c|c|c|c|c|c|c|c|}
\hline \multirow{2}{*}{$\begin{array}{l}\text { Initial concentration } \\
\qquad\left(\mathrm{mgg}^{-1}\right)\end{array}$} & \multirow[b]{2}{*}{$q_{e, \exp }\left(\mathrm{mgg}^{-1}\right)$} & \multicolumn{4}{|c|}{ First order kinetic model } & \multicolumn{4}{|c|}{ Second order kinetic model } \\
\hline & & $\begin{array}{c}k_{1} \\
\left(\mathrm{~h}^{-1}\right)\end{array}$ & $\begin{array}{c}q_{e,, c a l} \\
\left(\mathrm{mgg}^{-1}\right)\end{array}$ & $R^{\prime \prime \prime 2 " ' s}$ & $\begin{array}{l}\mathrm{SSE} \\
(\%)\end{array}$ & $\begin{array}{c}k_{2} \\
\left(\mathrm{~g}(\mathrm{mgh})^{-1}\right)\end{array}$ & $\begin{array}{c}q_{e,, c a l} \\
\left(\mathrm{mgg}^{-1}\right)\end{array}$ & $R^{2}$ & $\begin{array}{l}\text { SSE } \\
(\%)\end{array}$ \\
\hline 100 & 67.5 & 0.637 & 76.02 & 0.87 & 3.81 & 0.0154 & 69.93 & 0.99 & 0.432 \\
\hline 200 & 154.8 & 0.612 & 236.28 & 0.94 & 36.44 & 0.0084 & 156.25 & 0.99 & 0.648 \\
\hline 300 & 232.5 & 0.595 & 326.36 & 0.77 & 41.98 & 0.0031 & 243.90 & 0.99 & 5.098 \\
\hline 400 & 321.3 & 0.334 & 415.72 & 0.96 & 42.22 & 0.0021 & 335.42 & 0.99 & 6.315 \\
\hline 500 & 410.2 & 0.327 & 524.71 & 0.96 & 51.21 & 0.0013 & 430.78 & 0.99 & 9.204 \\
\hline
\end{tabular}

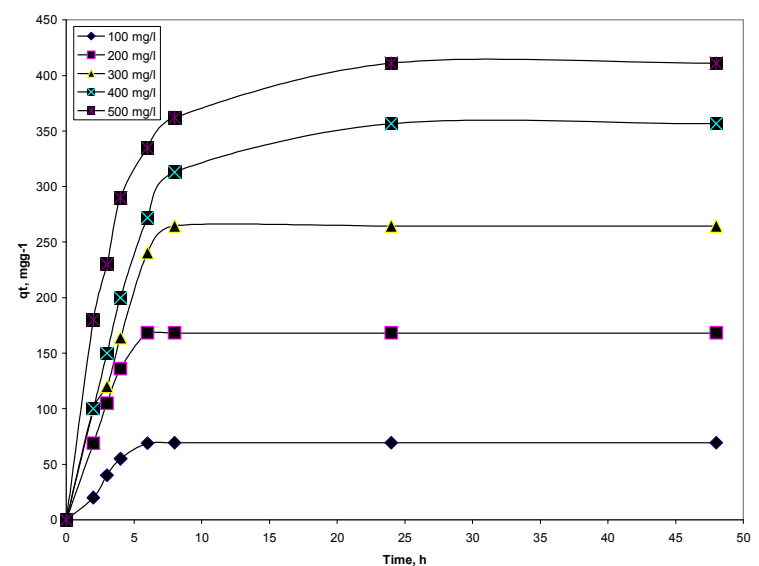

Fig. 2. The variation of adsorption capacity with adsorption time at various initial $\mathrm{MB}$ concentrations at $25{ }^{\circ} \mathrm{C}$ $(\mathrm{pH} 7, \mathrm{~W}=0.2 \mathrm{~g})$

\subsection{Adsorption kinetics}

The pseudo first-order equation. The rate constant of adsorption is determined from the pseudo first-order equation given by Langergren and Svenska [36]:

$$
\ln \left(q_{e}-q_{t}\right)=\ln q_{e}-k_{1} t
$$

where $q_{e}$ and $q_{t}$ are the amounts of the MB adsorbed $\left(\mathrm{mg} \mathrm{g}^{-1}\right)$ at equilibrium and at time $t(\mathrm{~min})$, respectively, and $k_{1}$ the rate constant adsorption $\left(\mathrm{h}^{-1}\right)$. Values of $k_{l}$ were calculated from the plots of $\ln \left(q_{e}-q_{t}\right)$ versus $t$ for different concentrations of the MB. The correlation coefficient values at high concentrations are higher than 0.70 , the experimental $q_{\mathrm{e}}$ values do not agree with the calculated ones, obtained from the linear plots (Table 1). This shows that the adsorption of the MB onto treated sawdust is not the first-order kinetics.
The pseudo second-order equation. The pseudo second-order equation based on equilibrium adsorption [37] is expressed as:

$$
1 / q_{t}=1 / k_{2} q_{e}^{2}+\left(1 / q_{t}\right) t
$$

where $k_{2}(\mathrm{~g} / \mathrm{mg} \mathrm{h})$ is the rate constant of the second-order adsorption. If the second-order kinetics is applicable, the plot of $t / q$ versus $t$ should show a linear relationship. There is no need to know any parameter beforehand and $q_{\mathrm{e}}$ and $k_{2}$ can be determined from the slope and intercept of the plot. Also, this procedure is more likely to predict the behaviour over the whole range of adsorption. The linear plots of $t / q$ versus $t$ (Fig. 3) show a good agreement between experimental and calculated $q_{\mathrm{e}}$ values (Table 1 ).

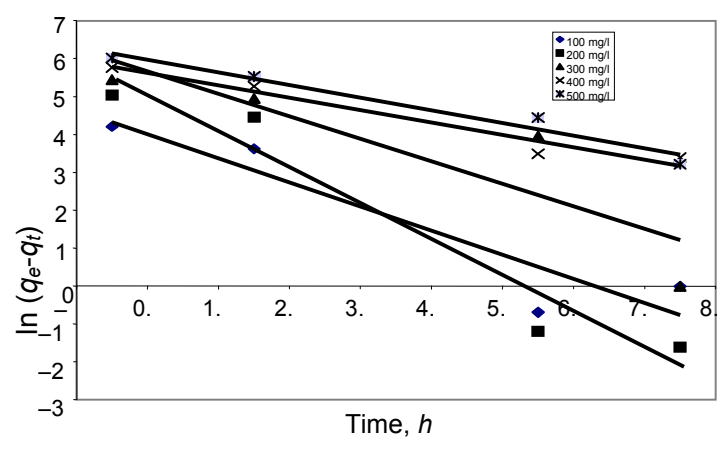

Fig. 3. Pseudo-first order kinetics for adsorption of the MB using treated sawdust at $25{ }^{\circ} \mathrm{C}$

The correlation coefficients for the secondorder kinetic model are greater than 0.9 indicating the applicability of this kinetic equation and the second-order nature of the adsorption process of the MB on treated sawdust. 


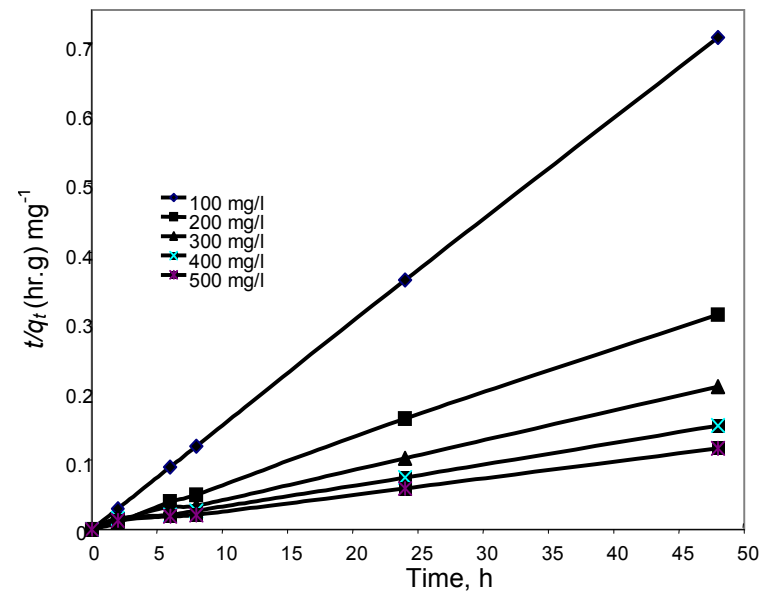

Fig. 4. Pseudo-second order kinetics for adsorption of the MB using treated sawdust at $25{ }^{\circ} \mathrm{C}$.

The Elovich equation. The Elovich equation based on equilibrium adsorption [38] is generally expressed as:

$$
q_{t}=1 / \beta \ln (\alpha \beta)+1 / \beta \ln (t)
$$

where: $\alpha$ is the initial adsorption rate $\left(\mathrm{mg} \mathrm{g}^{-1} \mathrm{~min}^{-1}\right)$, $\beta$ is the desorption constant $\left(\mathrm{g} \cdot \mathrm{mg}^{-1}\right)$ during any experiment. If the adsorption fits the Elovich model, a plot of $q_{t}$ vs. $\ln (t)$ should yield a linear relationship with a slope of $(1 / \beta)$ and an intercept of $(1 / \beta) \ln (\alpha \beta)$. The graph of the Elovich model for the adsorption of the MB by activated carbon produced from treated sawdust at $25{ }^{\circ} \mathrm{C}$ is shown in Fig 5.

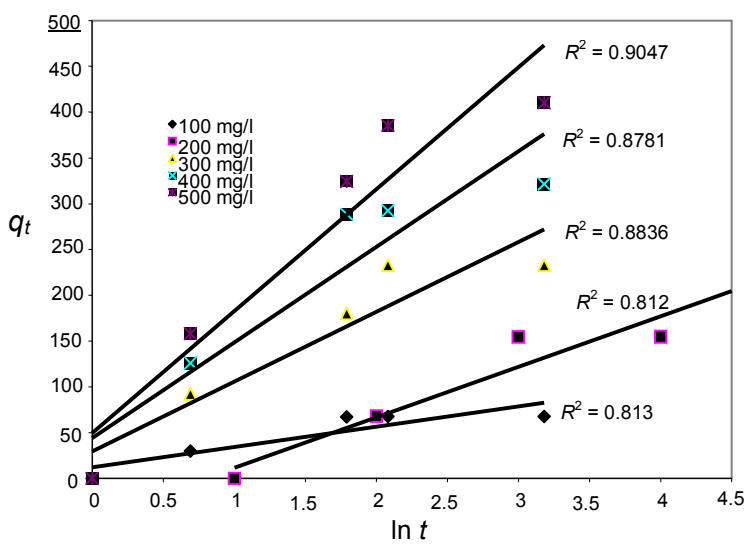

Fig. 5. The Elovich model for the adsorption of the MB using treated sawdust at $25^{\circ} \mathrm{C}$
The intraparticle diffusion model. The intraparticle diffusion model $[38,39]$ is expressed as

$$
R=K_{i d}(t)^{a}
$$

A linearised form of the equation is followed by

$$
\log R=\log K_{i d}+a \log (t)
$$

where: $R$ is the percent of the MB adsorbed, $t$ is the contact time (hr), " $a$ " is the gradient of linear plots, $K_{i d}$ is the intraparticle diffusion rate constant $\left(h r^{-1}\right)$, " $a$ " depicts the adsorption mechanism. $K_{i d}$ is taken as a rate factor, i.e. percent of the MB adsorbed per unit time. If the mechanism of adsorption fits the intraparticle diffusion model, then a plot of $\log R$ against $\log t$ will yield a straight line with a slope " $a$ " and an intercept of $\log K_{i d}$. The intraparticle diffusion model for the adsorption of the MB by activated carbon produced from treated sawdust at $25^{\circ} \mathrm{C}$ is shown in Fig 6 . The values of $K_{i d}$ were calculated from the slope of such plots and the $R^{2}$ values led to the conclusion that the intraparticle diffusion process is the rate-limiting step. Higher values of $K_{i d}$ illustrate an enhancement in the rate of adsorption; such high $K_{i d}$ values illustrate a better adsorption mechanism, which is related to an improved bounding between the MB and the adsorbent particles (Table 2). [40].

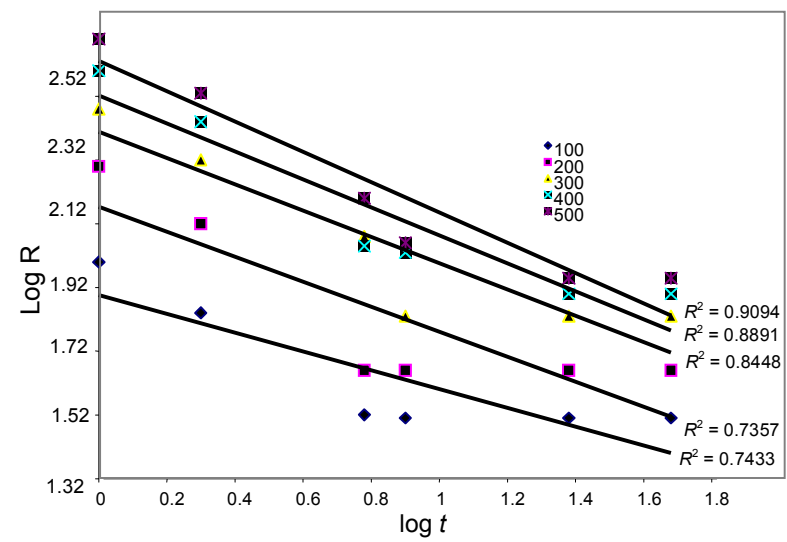

Fig. 6. The intraparticulate diffusion model for the adsorption of the MB using treated sawdust at $25{ }^{\circ} \mathrm{C}$ 
Table 2

Comparison of the intraparticle and the Elovich kinetic model values for different initial dye concentrations

\begin{tabular}{cccccccc}
\hline \hline $\begin{array}{c}\text { Initial } \\
\text { concentration } \\
\left(\mathrm{mg} \mathrm{l}^{-1}\right)\end{array}$ & \multicolumn{6}{c}{ Intaparticle kinetic model Elovich kinetic model } \\
\hline 100 & 78.723 & 0.295 & 0.7433 & 203.50 & 0.1512 & 0.9324 \\
200 & 149.000 & 0.393 & 0.7357 & 176.29 & 0.1175 & 0.7845 \\
300 & 255.918 & 0.413 & 0.8448 & 155.90 & 0.0441 & 0.8336 \\
400 & 333.426 & 0.440 & 0.8891 & 111.70 & 0.0436 & 0.8228 \\
500 & 427.563 & 0.475 & 0.9094 & 106.50 & 0.0257 & 0.8557 \\
\hline \hline
\end{tabular}

\subsection{Test of kinetic models}

Besides the value of $R^{2}$, the applicability of the two kinetic models are verified through the sum of error squares (SSE, \%). The adsorption kinetics of the $\mathrm{MB}$ on treated sawdust derived from treated sawdust was tested at different initial concentrations. The validity of each model was determined by the sum or error squares (SSE, \%) given by:

$$
\operatorname{SSE}(\%)=\sqrt{\frac{\sum\left(q_{e}, \exp -q_{e}, c a l\right)^{2}}{N}}
$$

where $N$ is the number of data points. The higher is the value of $R^{2}$ and the lower is the value of SSE; the better the goodness of fit will be. Table 1 lists the calculated results. It was found that the adsorption of methylene blue on AC produced from treated sawdust can be best described by the second-order kinetic model. Similar phenomena processes have been observed in the adsorption of direct dyes on treated sawdust prepared from sawdust [41] and adsorption of Congo red dye on treated sawdust from coir pith [42].

\subsection{Adsorption isotherms}

The adsorption isotherm indicates how the adsorption molecules distribute between the liquid phase and the solid phase when the adsorption process reaches an equilibrium state. The analysis of equilibrium adsorption data by fitting them to different isotherm models is an important step to find the suitable model that can be used for design purposes [43]. The adsorption isotherm study is carried out on two well-known isotherms, the
Langmuir and the Freundlich adsorption isotherm models. The Langmuir isotherm assumes monolayer adsorption onto a surface containing a finite number of adsorption sites of uniform strategies of adsorption with no transmigration of adsorbate in the plane of surface [44]. While, the Freundlich isotherm model assumes heterogeneous surface energies, in which the energy term in the Langmuir equation varies as a function of the surface coverage [45]. The applicability of the isotherm equation is compared by judging the correlation coefficients, $R^{2}$.

Langmuir isotherm. The linear form of the Langmuir isotherm model is given by the following equation:

$$
C_{\mathrm{e}} / q_{\mathrm{e}}=1 / Q_{\mathrm{o}} b+\left(1 / Q_{\mathrm{o}}\right) C_{\mathrm{e}}
$$

where $C_{\mathrm{e}}$ is the equilibrium concentration of the adsorbate (MB) (mg/l), $q_{\mathrm{e}}$, the amount of adsorbate adsorbed per unit mass of adsorbate $\left(\mathrm{mg} \mathrm{g}^{-1}\right)$, and $Q_{\mathrm{o}}$ and $b$ are the Langmuir constants related to the monolayer adsorption capacity and affinity of adsorbent towards adsorbate, respectively. When $C_{\mathrm{e}} / q_{\mathrm{e}}$ was plotted against $C_{\mathrm{e}}$, a straight line with slope of $1 / Q_{o}$ was obtained (Fig. 7), indicating that the adsorption of the MB on treated sawdust produced from treated sawdust follows the Langmuir isotherm. The Langmuir constants ' $b$ ' and ' $Q_{0}$ ' were calculated from this isotherm and their values are given in Table 3.

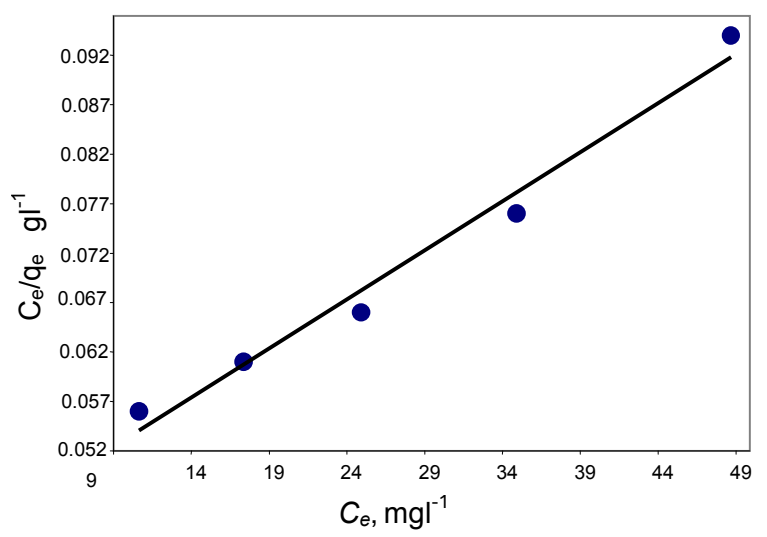

Fig. 7. The Langmuir adsorption isotherm of the MB using treated sawdust at $25{ }^{\circ} \mathrm{C}$

Conformation of the experimental data into the Langmuir isotherm model indicates the homogeneous nature of the treated sawdust carbon surface, i.e. each dye molecule/treated sawdust carbon adsorption has equal adsorption activation 
energy. The results also demonstrate the formation of monolayer coverage of dye molecule at the outer surface of activated carbon derived from sawdust. Similar observation was reported by the adsorption of acid orange 10 dye onto treated sawdusts prepared from agricultural waste bagasse [46] and by the adsorption of direct dyes on treated sawdust [41] and adsorption of the Congo red dye on treated sawdust from coir pith [42].

Table 3

\section{The Langmuir and the Freundlich isotherm constants for the $\mathrm{MB}$ at $25^{\circ} \mathrm{C}$}

\begin{tabular}{ll}
\hline \hline Langmuir isotherm & \\
\hline$Q_{\mathrm{o}}\left(\mathrm{mg} \mathrm{g}^{-1}\right)$ & $263.16 \pm \mathbf{0 . 0 3}$ \\
$B(\mathrm{~L} / \mathrm{mg})$ & $0.007 \pm \mathbf{0 . 0 4}$ \\
$R_{2}$ & $0.9873 \pm \mathbf{0 . 0 2}$ \\
$R_{L}$ & $0.222 \pm \mathbf{0 . 0 1}$ \\
\hline Freundlich isotherm & \\
\hline$\frac{1}{n}$ & $0.5252 \pm \mathbf{0 . 0 2}$ \\
$K_{F}\left[\left(\mathrm{mgg}^{-1}\right)\left(\mathrm{mg}^{-1}\right)^{1 / \mathrm{n}}\right]$ & $58.56 \pm \mathbf{0 . 0 3}$ \\
$R^{2}$ & $0.9471 \pm \mathbf{0 . 0 1}$ \\
\hline \hline
\end{tabular}

All values are means of triplicates $\pm \mathrm{SD}$

The essential characteristics of the Langmuir isotherm can be expressed in terms of a dimensionless equilibrium parameter $\left(R_{\mathrm{L}}\right)$ [47, 48], which is defined by:

$$
R_{\mathrm{L}}=1 /\left(1+b C_{0}\right)
$$

where $b$ is the Langmuir constant and $C_{0}$ the highest dye concentration $\left(\mathrm{mg} \mathrm{l}^{-1}\right)$. The value of $R_{\mathrm{L}}$ indicates the type of the isotherm to be either unfavorable $\left(R_{\mathrm{L}}>1\right)$, linear $\left(R_{\mathrm{L}}=1\right)$, favorable $\left(0<R_{\mathrm{L}}\right.$ $<1)$ or irreversible $\left(R_{\mathrm{L}}=0\right)$. The value of $R_{\mathrm{L}}$ was found to be 0.02 and confirmed that the treated sawdust is favorable for adsorption of the MB dye under conditions used in this study.

Freundlich isotherm. The well-known logarithmic form of the Freundlich model is given by the following equation:

$$
\log q_{\mathrm{e}}=\log K_{\mathrm{F}}+(1 / n) \log C_{\mathrm{e}}
$$

where $q_{\mathrm{e}}$ is the amount adsorbed at equilibrium $\left(\mathrm{mg} \mathrm{g}^{-1}\right), C_{\mathrm{e}}$ the equilibrium concentration of the adsorbate (MB) and $K_{\mathrm{F}}$ and $n$ are the Freundlich constants, $n$ giving an indication of how favorable the adsorption process and $K_{\mathrm{F}}\left(\mathrm{mg} \mathrm{g}^{-1}\left(1 \mathrm{mg}^{-1}\right)^{n}\right)$ is the adsorption capacity of the adsorbent. $K_{\mathrm{F}}$ can be defined as the adsorption or a distribution coefficient and represents the quantity of dye adsorbed onto treated sawdust adsorbent for a unit equilibrium concentration.

The slope $1 / n$ ranging between 0 and 1 is a measure of adsorption intensity or surface heterogeneity, becoming more heterogeneous as its value gets closer to zero [43]. A value for $1 / n$ below one indicates a normal Langmuir isotherm while $1 / n$ above one is indicative of cooperative adsorption [44]. The plot of $\log q_{\mathrm{e}}$ versus $\log C_{\mathrm{e}}$ gives straight lines with slope of ' $1 / n$ ' (Fig. 8), which shows that the adsorption of the MB also follows the Freundlich isotherm. Accordingly, Freundlich constants $\left(K_{\mathrm{F}}\right.$ and $\left.n\right)$ were calculated and recorded in Table 3.

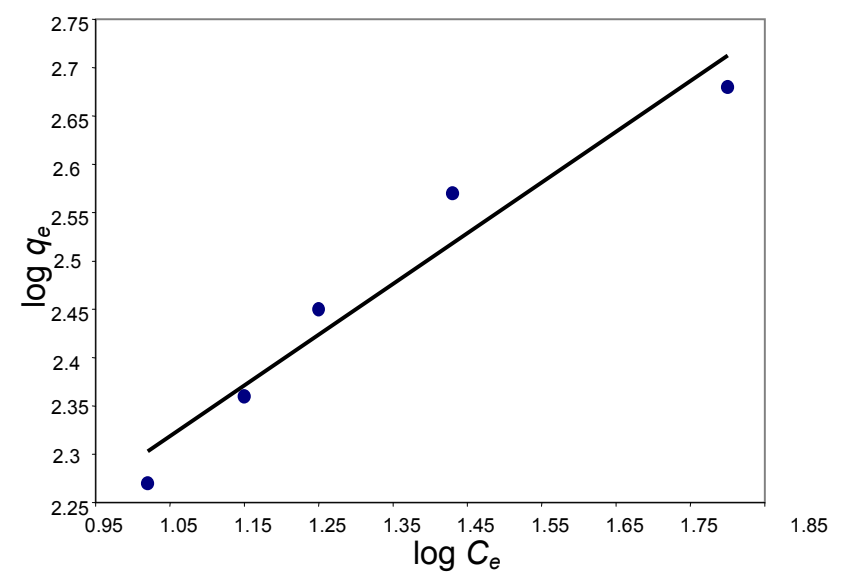

Fig. 8. The Freundlich adsorption isotherm of the MB using sawdust at $25^{\circ} \mathrm{C}$

Table 3 shows the values of the parameters of the two isotherms and the related correlation coefficients. As seen from Table 3, the Langmuir model yields a somewhat better fit $\left(R^{2}=0.9873\right)$ than the Freundlich model $\left(R^{2}=0.9471\right)$. As also illustrated in Table 3, the value of $1 / n$ is 0.5252 , which indicates favorable adsorption [48].

This work has shown that utilization of treated sawdust will be useful in the treatment of methylene blue dyes from industrial waste effluents; it will also eliminate various ecological problems that these waste effluents could cause. 


\section{CONCLUSIONS}

The present investigation has shown that treated sawdust can be effectively used as a raw material for the removal of methylene blue dye from aqueous solution over a wide range of concentration. Methylene blue is found to adsorb strongly on the surface of treated sawdust. The effect of various reagents used for desorption studies shows that hydrochloric acid is a better reagent for desorption, because we could get more than $90 \%$ removal of adsorbed dyes. Also, the adsorbent exhibits a stable structure towards this reagent. The desorption of dyes by mineral acids indicates that the dyes are adsorbed onto treated sawdust by physisorption. The adsorption behaviour is described by a monolayer Langmuir type isotherm. Kinetic data follows the pseudo second-order kinetic model. The value of the maximum adsorption capacity, $Q_{0},\left(263.16 \mathrm{mg} \mathrm{g}^{-1}\right)$ is comparable with the values for commercial treated sawdust reported in earlier studies.

\section{APPENDIX A.}

Chemical structure of methylene blue dye

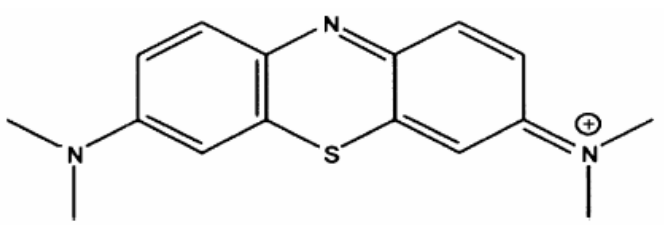

Methylene Blue [3, 9-bis dimethylaminophenazo thionium chloride]

Basic Blue 9, C.I. 52015, $\lambda_{\max }=668 \mathrm{~nm}$

\section{REFERENCES}

[1] Downham A., Collins P., Coloring our foods in the last and next millennium. International Journal of Food Science and Technology, 35, 5-22. (2000).

[2] Zollinger H., Synthesis, Properties and applications of organic dyes and pigments, color chemistry, 2nd revised edition, New York: VCH, 1991.

[3] Poots V. J. P., McKay G., Healy J. J., Removal of acid dye from effluent using natural adsorbents. 1. Peat. Water Research, 10, 1061-1066 (1976).

[4] Poots V. J. P., McKay G., Healy J. J., Removal of acid dye from effluent using natural adsorbents. 2. Wood. Water Research, 10, 1067-1070 (1976).

[5] McKay G., Otterburn M. S., Aga A. J., Fullers earth and fired clay as adsorbents for dyestuffs - equilibrium and rate studies. Water Air Soil Pollution, 24, 307-322 (1985).

[6] Nyholm N., Jacobsen B. N., Pederson B. M, Poulsen O., Damborg A., Schultz B., Removal of organic micro pollutants at ppb levels in laboratory activated-sludge reactors under various operating conditions - biodegradation. Water Research, 26, 339-353 (1992).

[7] Mavros P., Daniilidou A. C., Lazaridis N. K., Stergiou L., Color removal from aqueous-solutions. 1. Flotation. Environmental Technology, 15, 601-616 (1994).

[8] Ghosh D., Bhattacharyya K. G., Adsorption of methylene blue on kaolinite. Applied Clay Science, 20, 295-300 (2002).

[9] Avom J., Mbadcam J. K., Noubactep C., Germain P., Adsorption of methylene blue from an aqueous solution on to activated carbons from palm-tree cobs. Carbon, 35, 365-369 (1997).

[10] Chen B., Hui C. W., McKay G., Pore-surface diffusion modeling for dyes from effluent on pith. Langmuir, 17, 740-748 (2001).

[11] Kannan N., Sundaram M. M., Kinetics and mechanism of removal of methylene blue by adsorption on various carbons. - A comparative study. Dyes and Pigments, 51, 2540 (2001).

[12] Prado Alexandre G. S., Torres Jocilene D., Faria Elaine A., Dias Sílvia C. L., Comparative adsorption studies of indigo carmine dye on chitin and chitosan. Journal of Colloid and Interface Science, 277, 43-47 (2004).

[13] Allen S. J., Koumanova B., Depolarization of water/wastewater using adsorption (review). Journal of the University of Chemical Technology and Metallurgy, 40, 175-192 (2005).

[14] Srivastava V. C., Mall I. D., Mishra I. M., Characterization of mesoporous rice husk ash (RHA) and adsorption kinetics of metal ions from aqueous solution onto RHA. Journal of Hazardous Materials, B134, 257-267 (2006).

[15] Hajjaji M., Alami A., El Bouadili A., Removal of methylene blue from aqueous solution by fibrous clay minerals. Journal of Hazardous Materials, B135, 188-192 (2006).

[16] Mittal A., Kurup L., Gupta V. K., Use of waste materials - bottom ash and de-oiled soya, as potential adsorbents for the removal of Amaranth from aqueous solutions. Journal of Hazardous Materials, B117, 171-178 (2005).

[17] Mittal A., Mittal J., Kurup L., Singh A. K., Process development for the removal and recovery of hazardous dye erythrosine from wastewater by waste materials - bottom ash and de-oiled soya as adsorbents. Journal of Hazardous Materials, B138, 95-105 (2006).

[18] Mittal A., Malviya A., Kaur D., Mittal J., Kurup L., Studies on the adsorption kinetics and isotherms for the removal and recovery of methyl orange from wastewaters using waste materials. Journal of Hazardous Materials, 148, 229-240 (2007).

[19] Wang S., Soudi M., Li L., Zhu Z. H., Coal ash conversion into effective adsorbents for removal of heavy metals and dyes from wastewater. Journal of Hazardous Materials, B133, 243-251 (2006).

[20] Hamdaoui O., Dynamic sorption of methylene blue by cedar sawdust and crushed brick in fixed bed columns. Journal of Hazardous Materials, B138, 293-303 (2006). 
[21] Aksu Z. U., Isoglu I. A., Use of agricultural waste sugar beet pulp for the removal of Gemazol turquoise blue-G reactive dye from aqueous solution. Journal of Hazardous Materials, B137, 418-430 (2006).

[22] Malkoc E., Nuhoglu Y., Removal of Ni (II) ions from aqueous solutions using waste of tea factory: Adsorption on a fixed-bed column. Journal of Hazardous Materials, B135, 328-336 (2006).

[23] Mittal A., Adsorption kinetics of removal of a toxic dye, malachite green, from wastewater by using hen feathers. Journal of Hazardous Materials, B133, 196-202 (2006).

[24] Gupta V. K., Mittal A., Kurup L., Mittal J., Adsorption of a hazardous dye, erythrosine, over hen feathers. Journal of Colloid and Interface Science, 304, 52-57 (2006).

[25] Gupta V. K., Mohan D., Sharma S., Sharma M., Removal of basic dyes (Rhodamine-B and Methylene blue) from aqueous solutions using bagasse fly ash. Separation Science Technology, 35, 2097-2113 (2000).

[26] Gupta V. K, Ali I., Saini V. K., Gerven T. V., Der Bruggen B. V., Vandecasteele C., Removal of dyes from wastewater using bottom ash. Industrial and Engineering Chemistry Research, 44, 11, 3655-3664 (2005).

[27] Gupta V. K., Ali I., Suhas, Mohan D., Equilibrium Uptake and sorption dynamics for the removal of a basic dye (basic red) using low cost adsorbents. Journal of Colloid and Interface Science, 265, 257-64 (2003).

[28] Gupta V. K., Ali I., Saini V. K., Suhas, Removal of rhodamine B, fast green and methylene blue from wastewater using red mud - an aluminum industry waste. Industrial and Engineering Chemistry Research, 43, 1740-1747 (2004).

[29] Jain A. K., Gupta V. K., Bhatnagar A., Jain S., Suhas. A comparative assessment of adsorbents prepared from industrial wastes for the removal of cationic dye, Journal of Indian Chemical Society, 80, 267-270 (2003).

[30] Bello O. S., Adeogun A. I., Ajaelu, C. J. and Fehintola E. $\mathrm{O}$,. Adsorption of methylene blue onto activated carbon derived from periwinkle shells: Kinetics and equilibrium studies. Chemistry and Ecology, 24, 4, 285-295 (2008).

[31] D. Ghosh, K. G. Bhattacharyya, Adsorption of methylene blue on kaolinite, Appl. Clay Sci., 20, 295-300 (2002).

[32] J. Avom, J. K. Mbadcam, C. Noubactep, P. Germain, Adsorption of methylene blue from an aqueous solution onto activated carbon from palm-tree cobs, Carbon, 35, 365-369 (1997).

[33] G. F. Huang, Q. T. Wu, J. W. C. Wong, B. B. Nagar, Transformation of organic matter during co-composting of pig manure with sawdust, Bioresource Technology, 35, 132-137 (2005).

[34] C. Namasivayam, R. T, Yamuna. Adsorption of Direct red $12 \mathrm{~B}$ by biogas residual slurry. Equilibrium and rate processes. Environmental Pollution, 89, 1-8 (2005).
[35] M. Hema, S. Arivoli. Comparative study on the adsorption kinetics and thermodynamics of dyes onto acid activated low cost carbon. International Journal of Physical Sciences, 2 (1), 10-17 (2007).

[36] S. Lagergren, B. K. Svenska, Zur Theorie der Sogenannten Adsorption Geloester Stoffe, Kungliga Svenska Vetenskapsakademiens Handlingar, Band, 24 (4), 1-39 (1898).

[37] Ho, Y. S and Mckay, G., Kinetic models for the sorption of dye from aqueous solution by wood. Process Safety and Environmental Protection, 76 (B2), 183-191 (1998).

[38] S. H. Chien and W. R. Clayton. Application of Elovich equation to the kinetics of phosphate release and sorption on soils. Soil Science Society American Journal, 44, 265268 (1980).

[39] W. J. Weber and J. C. Morris. Kinetics of adsorption on carbon from solution. Journal of Sanitation Engineering, Division of American Society Civil Engineering, 89, 3160 (1963).

[40] E. Demirbasa, M. Kobyab, E. Senturkb, T. Ozkana, Adsorption kinetics for the removal of chromium (VI) from aqueous solutions on the activated carbons prepared from agricultural wastes. Water $S A$, 30, 4, 533-540 (2004).

[41] P. K. Malik, Dye removal from wastewater using activated carbon developed from sawdust: adsorption equilibrium and kinetics, Journal of Hazardous Material, B113, 81-88 (2004).

[42] C. Namasivayam, D. Kavitha, Removal of Congo red from water by adsorption onto activated carbon prepared from coir pith, an agricultural solid waste, Dyes Pigments, 54, 47-58 (2002).

[43] F. Haghseresht, G. Lu, Adsorption characteristics of phenolic compounds onto coal-reject-derived adsorbents, Energy Fuels, 12, 1100-1107 (1998).

[44] K. Fytianos, E. Voudrias, E. Kokkalis, Sorption-desorption behavior of 2,4-dichlorophenol by marine sediments, Chemosphere, 40, 3-6 (2000).

[45] T. W. Weber, R. K. Chakkravorti, Pore and solid diffusion models for fixedbed adsorbers, AIChE J., 20, 228 (1974).

[46] W. T. Tsai, C. Y. Chang, M. C. Lin, S. F. Chien, H. F. Sun, M. F. Hsieh, Adsorption of acid dye onto activated carbons prepared from agricultural waste bagasse by $\mathrm{ZnCl}_{2}$ activation, Chemosphere, 45, 51-58 (2001).

[47] K. R, Hall, L. C, Eagleton, A. Acrivos and T. Vermeulen, Pore and solid diffusion kinetics in fixed bed adsorption under constant pattern conditions. Industrial and Engineering Chemistry Fundamentals, 5 (2), 212-223 (1966).

[48] A. W. Adamson, Physical Chemistry of Surfaces, 5th ed., Wiley, New York, 1990. Pigments, 51, 25-40 (2001). 